\title{
THE ROLE OF PREOPERATIVE CARCINOEMBRYONIC ANTIGEN IN RECURRENCE OF RESECTABLE COLORECTAL CARCINOMA
}

\author{
Madiha Ali Khan ${ }^{1}$, Rab Nawaz Maken ${ }^{1}$,Hasan Nisar ${ }^{2}$, Ismat Fatima ${ }^{1}$, \\ Irfan Ullah Khan ${ }^{1}$, Misbah Masood ${ }^{1}$ and Abu Baker Shahid ${ }^{1}$ \\ ${ }^{1}$ Institute of Nuclear Medicine and Oncology (INMOL), Lahore, Pakistan; \\ ${ }^{2}$ Pakistan Institute of Engineering and Applied Sciences (PIEAS), Islamabad, Pakistan
}

\begin{abstract}
SUMMARY - In colorectal carcinoma, carcinoembryonic antigen (CEA) is a recommended marker for surveillance after curative resection. The aim of the present study was to determine the association of preoperative CEA with recurrence of colorectal carcinoma in our population. The study included 55 patients with all operable stages of colorectal adenocarcinoma treated during the 20122014 period, evaluated retrospectively and followed-up for recurrence for 2 years. Data on the baseline (preoperative) CEA levels were retrieved from patient files. On data analysis, SPSS 16.0 was used. In patients with normal preoperative CEA, the rate of recurrence was significantly low $(\mathrm{p}=0.008)$ and the likelihood of no recurrence 1.55-fold greater as compared to patients with raised initial CEA levels $(\mathrm{p}=0.028)$. In patients with raised preoperative CEA, the risk of recurrence was 5.26 -fold greater as compared to those with normal CEA levels $(\mathrm{p}=0.028)$. A significant weak positive correlation $\left(r_{s}=0.297\right)$ was found between raised CEA and recurrence. A highly significant $(p=0.002)$ moderate positive correlation was recorded in patients aged $<50$ and moderate positive correlation of borderline significance in males $\left(r_{\mathrm{s}}=0.324, \mathrm{p}=0.058\right)$. Sensitivity was $94.4 \%$ and specificity $32.4 \%$ in predicting recurrence. Accordingly, preoperative elevated CEA showed a significant weak positive correlation with recurrence while normal preoperative CEA moderately decreased the likelihood of recurrence.
\end{abstract}

Key words: Carcinoembryonic antigen; Colorectal neoplasm; Prognosis; Recurrence; Risk

\section{Introduction}

Colorectal carcinoma (CRC) is the third most common cancer in the world and second leading cause of death due to cancer ${ }^{1}$. In CRC, carcinoembryonic antigen (CEA) is a recommended marker for surveillance after curative resection ${ }^{2,3}$. It is the only reliable serum marker during follow up and consistent elevated CEA is an alarming sign of recurrent disease ${ }^{4}$. Preoperative elevated CEA has also been associated with poor prognosis and recurrence. Many current studies have strongly recommended its addition in current

Correspondence to: Ismat Fatima, PhD, Institute of Nuclear Medicine and Oncology, Lahore, Pakistan

E-mail: drismatfatima14@gmail.com

Received March 13, 2018, accepted September 26, 2019 staging system for CRC. Its role in treatment planning of patients undergoing curative resection is being studied extensively. The role of normal CEA levels in ruling out the possibility of either primary or recurrent $\mathrm{CRC}$ is also under consideration ${ }^{5-8}$.

The aim of the present study was to correlate preoperative CEA levels with recurrence in our local setting. Its variance with age, gender, stage and grade of disease was also studied.

\section{Patients and Methods}

It was a descriptive case series. Study population comprised diagnosed CRC patients registered in our hospital during the 2012-2014 period and meeting the inclusion criteria. Ethical approval from the institu- 


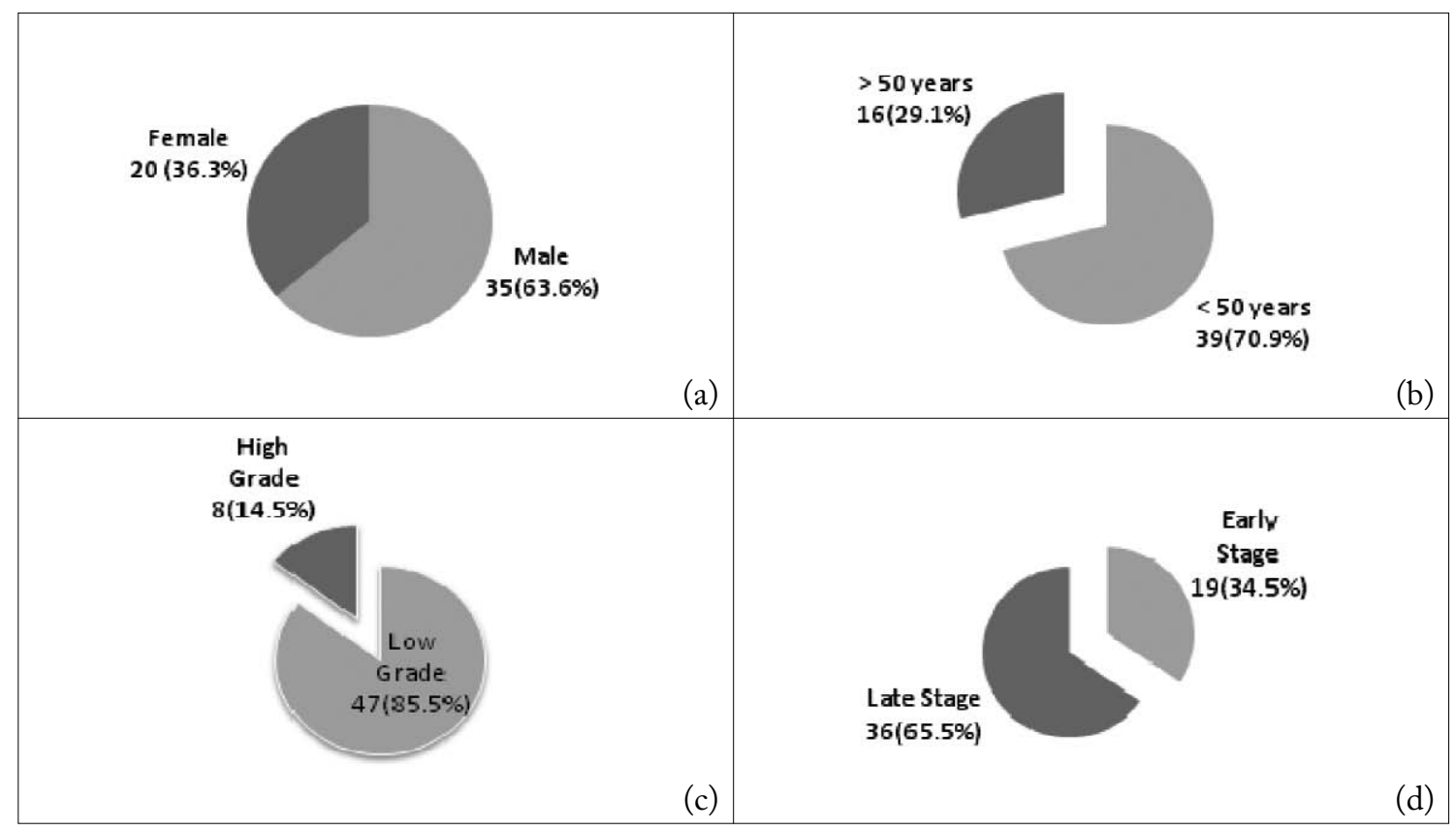

Fig. 1. Sample characteristics: (a) gender distribution of patient population; (b) patient distribution by age; (c) patient distribution by disease grade (d); patient distribution by disease stage.

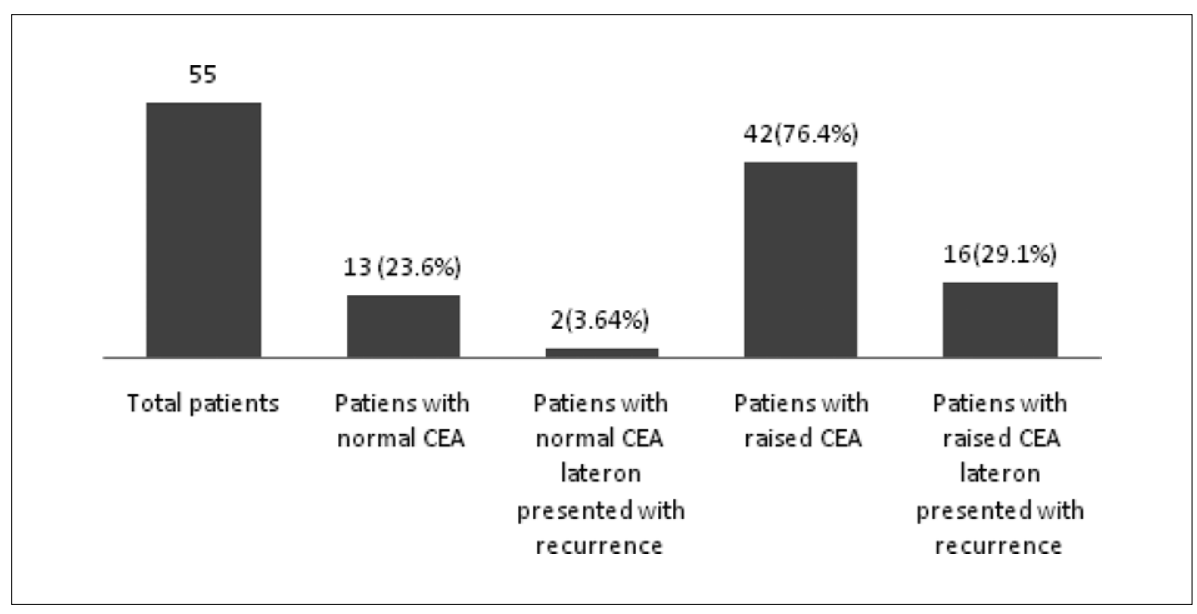

Fig. 2. Patient distribution according to carcinoembryonic antigen (CEA) levels.

tional review board was obtained prior to the study. It was a retrospective study, so patient consent was not required. Patients with all operable stages of colorectal adenocarcinoma and histopathologically proven colorectal adenocarcinoma with preoperative serum CEA levels recorded were included. Exclusion criteria were pregnancy and secondary malignancy.

Data were collected from archival case files of $\mathrm{pa}^{-}$ tients. Patients who did not present for follow up visit for at least two years after treatment were excluded. Patients that met the selection criteria and had presented for regular follow up made the population size for the study. Patients lost during the follow up period were contacted by telephone. Data on patient status were obtained from their relatives and recorded accordingly. Fifty-five CRC patients having baseline (preoperative) CEA levels were evaluated and followed-up for a period of 2 years. Serum CEA level $\leq 5$ 
Table 1. Correlation between disease recurrence variables and raised carcinoembryonic antigen (CEA) levels using Spearman correlation coefficient $\left(r_{s}\right)$ and relative risk $(R R)$

\begin{tabular}{|l|l|l|l|l|l|}
\hline Variable & Comparison type & $\begin{array}{l}\text { Correlation coefficient } \\
\text { for CEA vs. recurrence }\end{array}$ & Sig. (2-tailed) & $\begin{array}{l}\text { RR of recurrence in } \\
\text { raised CEA (95\% CI) }\end{array}$ & Sig. (2-tailed) \\
\hline Age (years) & $<50(\mathrm{n}=39)$ & 0.471 & 0.002 & NA & - \\
& $>50(\mathrm{n}=16)$ & -0.383 & 0.143 & NA & - \\
\hline Gender & Male $(\mathrm{n}=35)$ & 0.324 & 0.058 & $4.40(0.65-29.75)$ & 0.056 \\
& Female $(\mathrm{n}=20)$ & 0.275 & 0.241 & NA & - \\
\hline Stage & Early $(\mathrm{n}=19)$ & 0.218 & 0.370 & $2.30(0.34-15.69)$ & 0.342 \\
& Late $(\mathrm{n}=36)$ & 0.199 & 0.246 & $2.65(0.40-17.28)$ & 0.234 \\
\hline \multirow{2}{*}{ Grade } & High $(\mathrm{n}=8)$ & 0.000 & 1.000 & $1.00(0.20-4.95)$ & 1.00 \\
& Low $(\mathrm{n}=47)$ & 0.250 & 0.090 & $3.97(0.58-27.05)$ & 0.086 \\
\hline \multicolumn{2}{|l|}{ Overall $(\mathrm{N}=55)$} & 0.297 & 0.028 & $5.26(0.77-35.83)$ & 0.028 \\
\cline { 3 - 5 } & Normal CEA vs. no recurrence (RR) $1.55(1.15-2.08)$ & 0.028 \\
\hline
\end{tabular}

$\mathrm{NA}=$ not assessed (due to less than expected counts in either category)

$\mathrm{ng} / \mathrm{mL}$ was considered normal, whereas levels above this value were considered elevated.

Data on the variables of interest, i.e. age, gender, stage and grade of tumor were collected and then correlated with serum CEA levels of patients using SPSS v. 16. The $\chi^{2}$-test was used for nonparametric analysis of categorical variables. Continuous variables including age and preoperative CEA levels were dichotomized into categorical variables, as follows: age $>50$ and $<50$ years; and preoperative CEA levels $\leq 5 \mathrm{ng} / \mathrm{mL}$ considered normal and those $>5 \mathrm{ng} / \mathrm{mL}$ considered raised for statistical analysis. Stage was also dichotomized as early and late for calculating the risk estimate and correlation coefficient. Stage I and II patients were grouped together as early, and stage III termed as late stage patients.

Spearman coefficient (rho) was used to determine correlation coefficient. Risk estimates were calculated using $2 \times 2$ contingency tables and coordinates of the receiver operating characteristic (ROC) curve were used to assess sensitivity and specificity of the assay keeping recurrence as a state variable. Likelihood ratios were calculated using the formula: $L R+=$ sensitivity/1-specificity and $L R-=1$-sensitivity/specificity. The $p$ values less than 0.05 were considered significant.

\section{Results}

The present study comprised 55 patients with colorectal adenocarcinoma of all operable stages. Demo- graphic data are described in Figure 1. The male to female ratio was 1.75:1.00. Preoperative serum CEA levels were found to be high in $76.4 \%(\mathrm{n}=42, \mathrm{p}<0.0001)$ and recurrence was observed in $32.7 \%(n=18)$ of patients.

Normal CEA levels were significantly associated with no recurrence $(p=0.008)$. Thirteen patients had normal preoperative CEA levels and recurrence was observed in only two of them (Fig. 2). Relative risk (RR) estimates were calculated for normal CEA levels and probability of non-recurrent disease. Patient population with normal preoperative CEA levels had 1.55-fold greater likelihood to develop no recurrence as compared to patients with raised initial CEA levels. These results were statistically significant $(\mathrm{p}=0.028)$ (Table 1 ).

On the other hand, raised preoperative CEA significantly increased the risk of recurrence. The risk of disease recurrence was 5.26-fold greater in patients with raised initial CEA levels as compared to those with normal initial CEA levels ( $\mathrm{p}=0.028)$. When calculated for age, gender, stage and grade, RR did not reach statistical significance (Table 1 ).

We calculated correlation coefficients (rho) for overall raised preoperative CEA and recurrence. A significant weak positive correlation $\left(\mathrm{r}_{\mathrm{s}}=0.297, \mathrm{p}=0.028\right)$ was found between raised CEA and recurrence. When applied to the patient population aged $<50$, a highly significant $(p=0.002)$ moderate positive relationship was found between raised CEA and recurrence $\left(r_{s}=0.471\right)$. In male patients, moderate positive correlation of borderline significance $\left(r_{s}=0.324, p=0.058\right)$ was 
Table 2. Sensitivity, specificity, positive and negative likelihood ratios $(L R)$ of preoperative carcinoembryonic antigen in predicting recurrence

\begin{tabular}{|l|l|l|l|l|l|}
\hline Variable & Comparison type & Sensitivity $(\%)$ & Specificity $(\%)$ & LR+ & LR- \\
\hline Age (years) & $<50(\mathrm{n}=39)$ & 100 & 46.2 & 1.85 & - \\
& $>50(\mathrm{n}=16)$ & 80.0 & 0 & 0.80 & - \\
\hline \multirow{2}{*}{ Gender } & Male $(\mathrm{n}=35)$ & 91.7 & 39.1 & 1.50 & 0.21 \\
& Female $(\mathrm{n}=20)$ & 100 & 15.8 & 1.18 & - \\
\hline \multirow{2}{*}{ Stage } & Early $(\mathrm{n}=19)$ & 83.3 & 38.5 & 1.35 & 0.43 \\
& Late $(\mathrm{n}=36)$ & 91.7 & 25.0 & 1.22 & 0.33 \\
\hline \multirow{2}{*}{ Grade } & High $(\mathrm{n}=8)$ & 75 & 25 & 1.0 & 1.0 \\
& Low $(\mathrm{n}=47)$ & 92.9 & 30.3 & 1.33 & 0.23 \\
\hline Overall $(\mathrm{N}=55)$ & & 94.4 & 32.4 & 1.39 & 0.17 \\
\hline
\end{tabular}

found (Table 1). There was no significant correlation in the remaining parameters including age $>50$ years, female patients, low/high grade and early/late stage (Table 1).

Coordinates of the ROC curve were used to determine sensitivity and specificity of preoperative CEA levels in predicting recurrence. Keeping recurrence as positive actual state and considering serum CEA levels $>5 \mathrm{ng} / \mathrm{mL}$ as raised, sensitivity of the marker was $94.4 \%$ and specificity of the assay was $32.4 \%$ in predicting recurrence after curative resection.

In patients aged $<50$, a highly significant association was found between raised CEA and recurrence when calculating correlation coefficient. Sensitivity of the assay in predicting recurrence was $100 \%$, with $46.2 \%$ specificity in this group in concordance with the correlation coefficient. Sensitivity of the marker in predicting recurrence was low in early stage as compared with late stage ( $83.3 \%$ vs. 91.7\%). Likelihood ratios (LR+ and LR-) were also calculated (Table 2).

The value of $\mathrm{LR}+$ in the overall patient population was 1.39 , showing that raised preoperative CEA minimally increased the likelihood of recurrence. On the other hand, LR- was 0.17 showing that normal preoperative CEA indicated moderate decrease in the likelihood of recurrence.

\section{Discussion}

Colorectal carcinoma is the third most common cancer and has fatal outcome9. Preoperative CEA levels have shown relationship with disease prognosis in
CRC. Many studies have reported strong association between raised CEA levels and recurrence (serum CEA levels $>5 \mathrm{ng} / \mathrm{mL}$ are conventionally considered raised $)^{10,11}$. Previous literature has reported that CEA is an independent prognostic factor for CRC. However, some recent studies have demonstrated that prognostic efficiency of the marker is not equal in all stages of the disease; there are opinions that $5 \mathrm{ng} / \mathrm{mL}$ may not be an optimal cut off for predicting recurrence. Prognostic value of normal preoperative CEA is also an unresolved question ${ }^{12-16}$.

Our study revealed that a significant patient population with normal preoperative CEA levels had no disease recurrence (14 out of 16 cases free from recurrence, $p=0.008)$. The $R R$ of recurrence was also significantly lower in this group $(\mathrm{p}=0.028)$ and patients with normal CEA had 1.55-fold lower risk of recurrence. The lower and upper borders with $95 \%$ confidence intervals were close (95\% CI: 1.15-2.08) depicting precision as stated in Table 1.

In $\mathrm{CRC}, 30 \%-40 \%$ of patients are reported to have disease recurrence after curative resection ${ }^{17}$. In our study population, the rate of recurrence was $32.7 \%$ (18 out of 55 patients). A recent study showed that $77 \%$ of CRC patients who experienced recurrence had raised preoperative CEA levels, while 32\% had normal CEA. This percentage of study population with normal CEA having experienced recurrence was attributed to the fact that they may have had either early stage of tumor progression or a non-CEA producing tumor such as poorly differentiated carcinoma ${ }^{17}$.

In our study population, $88.9 \%$ of recurrences were recorded in patients with high preoperative CEA. 
Only $11.1 \%$ of patients having recurrence had normal preoperative CEA levels. Good correlation between CEA and recurrence is in concordance with literature data. In our patient population, there were $85.5 \%$ of well-differentiated (low-grade) tumors, which may have been the reason for better prognostic efficiency of the marker.

Correlation coefficient also supported the hypothesis and rho was 0.00 in patients with high preoperative CEA and recurrence. RR was also 1.00 showing no risk of recurrence in patients with elevated CEA having high-grade tumor. Patient population with low-grade (well-differentiated) tumor showed weak positive correlation between recurrence and raised preoperative CEA $\left(r_{s}=0.250\right)$; however, statistical significance was not reached $(\mathrm{p}=0.090)$, maybe due to the small sample size $(n=47)$. $R R$ of recurrence in this group was also increased about 4 times $(R R=3.97$ $(0.58-27.05=; \mathrm{p}=0.086)$ (Table 1$)$.

Overall sensitivity of the raised preoperative CEA in predicting recurrence was $94.4 \%$ and specificity 32.4\%. Positive predictive value (PPV) and negative predictive value (NPV) was $38.0 \%$ and $84.6 \%$, respectively. The marker was found to have high overall sensitivity but low specificity, and the false-positive rate was high. In the current study, out of 42 subjects with raised serum CEA levels, recurrence was recorded in $16(38.1 \%)$ cases. We recorded $61.9 \%(n=26)$ of falsepositive elevations of CEA in our study. Keeping the cut off of $7 \mathrm{ng} / \mathrm{mL}$ in a recent study, specificity of $84.1 \%$ was achieved but sensitivity decreased to $36.4 \%$ in predicting recurrence. The PPV and NPV remained $40.6 \%$ and $81.5 \%$, respectively, which was close to our data $(38.0 \% \text { vs. } 84.6 \%)^{18}$. Low sensitivity of the marker was observed in early stage as compared to late stage (83.3\% vs. 91.7\%) (Table 2). These results are in concordance with the literature and were attributed to low recurrence rate in early stage, thus increasing the falsepositive rate ${ }^{16}$.

Negative and positive likelihood ratios were also calculated. Generally, values $>10$ indicate large and often conclusive increase in the likelihood of disease, and values 1-2 minimally increase the likelihood of disease. If the value is 1 , it is indicative of no change in the likelihood of disease. Values 0.5-1.0 indicate minimal decrease in the likelihood of disease. Values 0.20.5 indicate small decrease, $0.1-0.2$ moderate decrease, and $<0.1$ indicate large and often conclusive decrease in the likelihood of disease.

In our study population, the likelihood of recurrence ranged from 0.17 to 1.85 (Table 2). In the overall study population, $\mathrm{LR}+$ was 1.39 . So, it was inferred that raised preoperative CEA minimally increased the likelihood of recurrence. However, LR-, which was 0.17 , showed that normal preoperative CEA moderately decreased the probability of recurrence. Our results favored the use of normal preoperative CEA in predicting nonrecurring disease more than the use of elevated preoperative CEA as a predictor of recurrence.

The best correlation of $L R+$ values $(L R+1.85)$ was found in the $<50$ age group. In high-grade patients, no change in the likelihood of disease was inferred from the results (LR+ 1 and LR- 1 ).

There were some limitations in the present study including limited sample size, inadequate and incomplete patient records leading to omission of certain patients who might have been included in the analysis. Moreover, an adequate control group of patients should be included in order to explore the role of serum CEA in CRC prognosis.

\section{Conclusions}

A significant patient population (14 out of 16; $\mathrm{p}=0.008$ ) with normal preoperative CEA levels were free from disease recurrence. RR of recurrence was 1.55 -fold lower in this group. Conversely, raised preoperative CEA significantly (5.26 times) increased the risk of recurrence as compared with those with normal CEA levels. In the patient population aged $<50$, a highly significant $(\mathrm{p}=0.002)$ moderate positive relationship was found between raised CEA and recurrence. Overall sensitivity of the raised preoperative CEA in predicting recurrence was $94.4 \%$ and specificity, PPV and NPV were $32.4 \%, 38.0 \%$ and $84.6 \%$, respectively.

\section{Acknowledgment}

We would like to thank Dr. Syed A Aziz, PhD, Faculty of Medicine, Department of Pathology and Laboratory Medicine, University of Ottawa, Canada, for his valuable assistance in the study. 


\section{References}

1. Rašić I, Rašić A, Akšamija G, Radović S. The relationship between serum level of malondialdehyde and progression of colorectal cancer. Acta Clin Croat. 2018;57:411-6. DOI: 10.20471/acc.2018.57.03.02

2. Locker GY, Hamilton S, Harris J, Jessup JM, Kemeny N, Macdonald JS, et al. ASCO 2006 update of recommendations for the use of tumor markers in gastrointestinal cancer. J Clin Oncol. 2006;24:5313-27. DOI: 10.1200/JCO.2006.08.2644

3. McNally GE, Lloyd DM, Grondona JP. Carcinoembryonic antigen as a prognostic factor in colorectal cancer with liver metastases. J Cancer Ther. 2015;6:1035-44. DOI: 10.4236/ jct.2015.612113

4. Bhatti I, Patel M, Dennison AR, Thomas MW, Garcea G. Utility of postoperative CEA for surveillance of recurrence after resection of primary colorectal cancer. Int J Surg. 2015;16: 123-8. DOI: 10.1016/j.ijsu.2015.03.002

5. Jeon BG, Shin R, Chung JK, Jung LM, Heo SC. Individualized cutoff value of the preoperative carcinoembryonic antigen level is necessary for optimal use as a prognostic marker. Ann Coloproctol. 2013;29:106-14. DOI: org/10.3393/ac.2013.29.3.106

6. Yang KM, Park LJ, Kim CW, Roh SA, Cho D, Kim JC. The prognostic significance and treatment modality for elevated pre- and postoperative serum CEA in colorectal cancer patients. Ann Surg Treat Res. 2016;91(4):165-71. DOI: 10.4174/ astr.2016.91.4.165

7. Chung MJ, Chung SM, Kim JU, Ryu MR. Prognostic significance of serum carcinoembryonic antigen normalization on survival in rectal cancer treated with preoperative chemoradiation. Cancer Res Treat. 2013;45(3):186-92. DOI: 10.4143/ crt.2013.45.3.186

8. Nazato DM, Matos LL, Waisberg DR, Souza JRM, Martins LC, Waisberg J. Prognostic value of carcinoembryonic antigen distribution in tumor tissue of colorectal carcinoma. Arq Gastroenterol. 2009;46:26-31. DOI: 10.1590/S0004-280320090 00100010

9. Mekić MS, Pedišić I, Šobat H, Boras VV, Kirac I, Štefančić L, et al. The role of complete blood count parameters in patients with colorectal cancer. Acta Clin Croat. 2018;57:624-9. DOI: 10.20471/acc.2018.57.04.03
10. Polat E, Duman U, Duman M, Atici AE, Reyhan E, Dalgic T, et al. Diagnostic value of preoperative serum carcinoembryonic antigen and carbohydrate antigen 19-9 in colorectal cancer. Curr Oncol. 2014;21:1-7. DOI: http://dx.doi.org/10.3747/ co.21.1711

11. Amri R, Bordeianou LG, Sylia P, Berger DL. Preoperative carcinoembryonic antigen as an outcome predictor in colon cancer. J Surg Oncol. 2013 Jul;108(1):14-8. DOI: 10.1002/ jso. 23352

12. Huh JW, Oh BR, Kim HR, Kim YJ. Preoperative carcinoembryonic antigen level as an independent prognostic factor in potentially curative colon cancer. J Surg Oncol. 2010;101: 396-400. DOI: $10.1002 /$ jso.21495

13. Kirat HT, Ozturk E, Lavery IC, Kiran RP. The predictive value of preoperative carcinoembryonic antigen level in the prognosis of colon cancer. Am J Surg. 2012;204:447-52. DOI: 10.1016/j. amjsurg.2011.11.007

14. Thirunavukarasu P, Sukumar S, Sathaiah M, Mahan M, Pragatheeshwar KD, Pingpank JF. C-stage in colon cancer: implications of carcinoembryonic antigen biomarker in staging, prognosis, and management. J Natl Cancer Inst. 2011;103: 689-97. DOI: 10.1093/jnci/djr078

15. Becerra AZ, Probst CP, Tejani MA, Aquina CT, Gonzalez MG, Hensley BJ, et al. Evaluating the prognostic role of elevated preoperative carcinoembryonic antigen levels in colon cancer patients: results from the National Cancer Database. Ann Surg Oncol. 2016;23:1554-61. DOI: org/10.1245/ s10434015-5014-1

16. Hara M, Sato M, Takahashi H, Takayama S, Takeyama H. Does serum carcinoembryonic antigen elevation in patients with postoperative stage II colorectal cancer indicate recurrence? Comparison with stage III. J Surg Oncol. 2010;102: 154-7. DOI: $10.1002 /$ jso. 21599

17. Bin-Bin Su, Hui Shi, Jun Wan. Role of serum carcinoembryonic antigen in the detection of colorectal cancer before and after surgical resection. World J Gastroenterol. 2012;18: 2121-6. DOI: 10.3748/wjg.v18.i17.2121

18. Park IJ, Choi GS, Lim KH, Kang BM, Jun SH. Serum carcinoembryonic antigen monitoring after curative resection for colorectal cancer: clinical significance of the preoperative level. Ann Surg Oncol. 2009;16:3087-93. DOI: 10.1245/s10434009-0625-z 


\title{
Sažetak \\ ULOGA PRIJEOPERACIJSKOG KARCINOEMBRIJSKOG ANTIGENA U RECIDIVIRANJU RESEKTABILNOG KOLOREKTALNOG KARCINOMA
}

\author{
M. A. Khan, R. N. Maken, H. Nisar, I Fatima, I. U. Khan, M. Masood i A. B. Shahid
}

U kolorektalnom karcinomu preporuča se karcinoembrijski antigen (CEA) kao biljeg u praćenju bolesnika nakon resekcije karcinoma. Cilj ovoga istraživanja bio je utvrditi udruženost prijeoperacijske razine CEA s recidiviranjem kolorektalnog karcinoma u našoj populaciji. U istraživanje je bilo uključeno 55 bolesnika sa svim operabilnim stadijima kolorektalnog adenokarcinoma liječenih u razdoblju od 2012. do 2014. godine. Bolesnici su retrospektivno procijenjeni i praćeni zbog recidiva tijekom dvije godine. Podaci o bazalnim (prijeoperacijskim) razinama CEA preuzeti su iz medicinske dokumentacije bolesnika. Analiza podataka provedena je pomoću SPSS 16.0. Kod bolesnika s normalnom prijeoperacijskom razinom CEA stopa recidiva bila je značajno niža $(\mathrm{p}=0,008)$, a vjerojatnost izostanka recidiva 1,55 puta veća u usporedbi s bolesnicima s povišenim početnim razinama CEA $(\mathrm{p}=0,028)$. Kod bolesnika s povišenim prijeoperacijskim razinama CEA rizik od recidiva bio je 5,26 puta veći u usporedbi s onim u bolesnika s normalnim razinama CEA ( $\mathrm{p}=0,028)$. Značajna slabo pozitivna korelacija $\left(r_{s}=0,297\right)$ utvrđena je između povišene razine CEA i recidiva. Visoko značajna $(p=0,002)$ umjereno pozitivna korelacija zabilježena je u bolesnika mlađih od 50 godina te umjereno pozitivna korelacija granične značajnosti kod muškaraca $\left(r_{s}=0,324, p=0,058\right)$. Utvrđena je osjetljivost od $94,4 \%$ i specifičnost od $32,4 \%$ u predviđanju recidiva. Dakle, povišena prijeopearcijska razina CEA pokazala je značajnu slabo pozitivnu korelaciju s recidivima, dok je normalna prijeoperacijska razina CEA umjereno snizila vjerojatnost recidiva.

Ključne riječi: Karcinoembrijski antigen; Kolorektalni karcinom; Prognoza; Recidiv; Rizik 